\title{
Intelligent Support for Decision-Making: A Conceptual Model
}

\author{
Malgorzata Nycz and Barbara Smok \\ Wroclaw University of Economics, Wroclaw, Poland
}

\author{
malgorzata.nycz@ae.wroc.pl barbara.smok@ae.wroc.pl
}

\begin{abstract}
This article presents a model of intelligent decision support using combined system that consists of two parts. The first part is responsible for classification of incoming cases into appropriate decision group, the second one realizes the inferring process in a deductive way. As an exemplary decisional situation we have considered situations when an unemployed persons claim for benefits.
\end{abstract}

Keywords: decision-making process, classification, deductive reasoning, unemployment

\section{Introduction}

The challenges of nowadays world force the newest methods and technology application to support the decision-making process and, in consequence, the importance of decision support systems is still increasing. Decision problems to be solved are often very complicated and require better and more powerful, often intelligent support tools. Sometimes, it is useful to generate the expertise set in some steps. Such a situation can be met when operating on very large databases and, on the other hand, solving problems are complicated. As an exemplary situation we have taken into consideration the situation of unemployment in Poland. This problem is urgent and complex. Databases that ought to be considered are very large. In our opinion, it is worth of attention to limit the searching space and then carry out looking for solutions within smaller spaces. Among many known methods and techniques used in decision support systems, we have chosen discriminant analyses for classification of cases and deductive approach to infer about solutions within developed classes. We are conscious that there are other methods that could be used in this exemplary situation. Our goal was to present the possibility how the social worker support in solving difficult problems could be realized. As far as we know, no any intelligent support system has been implemented in Poland.

\section{The Goal}

Our up-to-day environment affecting any decision-making tasks is becoming more and more complex. There are many different more or le ss intelligent systems supporting decision-making process. They are generally domains oriented. That means they carry out inferring basing only on a specific domain oriented knowledge base and expertise obtained may be not satisfying (Nycz \& Smok, 2001).

As an exemplary situation we have taken into consideration the situation of unemployment in Poland.

Material published as part of these proceedings, either on-line or in print, is copyrighted by Informing Science. Permission to make digital or paper copy of part or all of these works for personal or classroom use is granted without fee provided that the copies are not made or distributed for profit or commercial advantage AND that copies 1) bear this notice in full and 2) give the full citation on the first page. It is permissible to abstract these works so long as credit is given. To copy in all other cases or to republish or to post on a server or to redistribute to lists requires specific permission from the publisher at Publisher@InformingScience.org
The problem of unemployment, which was almost unknown in our country before the changes during the last 12-years, now is still increasing. In some regions of Poland it is estimated till $30 \%$, especially in smaller towns and villages where, in previous system, only one big factory or other enterprise existed that now it has been cancelled. According to the Polish Insurance Law dismissed 
workers obtain help from the state. But this help differs depending on some factors. It is not only simple giving money to the unemployed but also contains other forms of help. The problem is urgent and complicated. It is possible to distinguish some similarities among situations of people inquiring for benefits and, basing on it, deliver appropriate help. In our idea we propose to create a model that generates an advice to particular situation basing on previously made case classification and then further inferring to obtain a decision. Our main aim is to present how to support in intelligent way the process of delivering help to people who became unemployed. In fig.1 we present the idea of our approach.

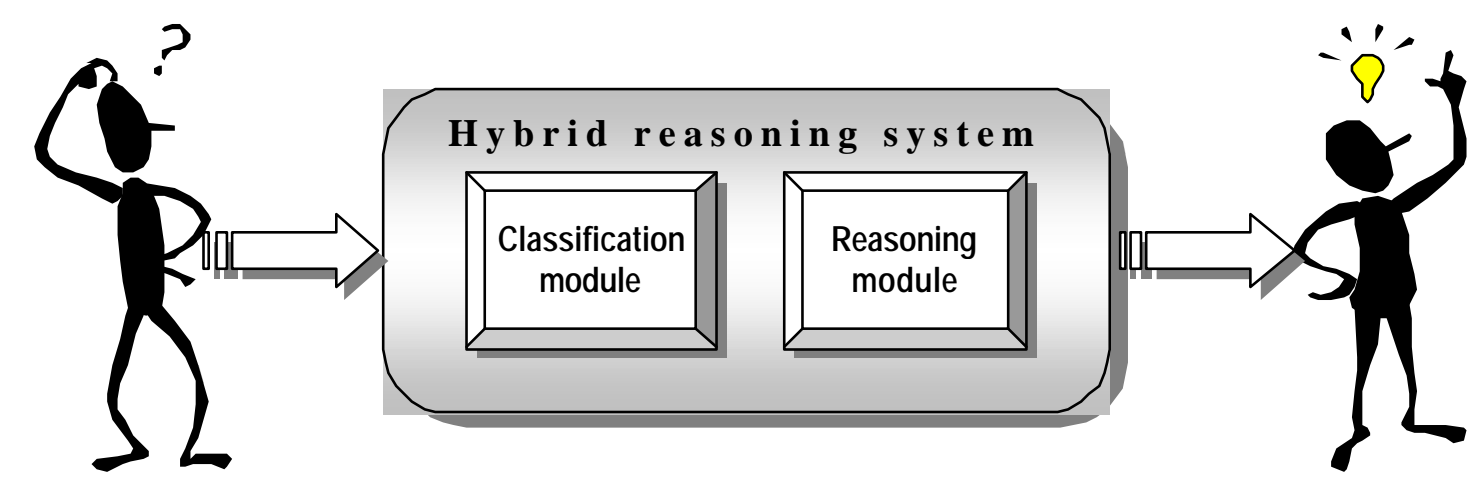

Fig.1: The idea of the reasoning system

The conceptual model consists of two main modules, which are the module responsible for classification of incoming cases into appropriate group that corresponds with the domain, and the module that realizes the reasoning process and generates expertise. It is in our case a deductive system.

\section{Situation Description}

The problem of unemployment is urgent because this phenomenon is still increasing. As we mentioned above, in some regions it depicts more then $30 \%$ of all potential workers. The causes of this situation are different. Workers can be dismissed by the employee, by the mselves, due to the group dismissing (e.g. when the enterprise has been cancelled) or due to disciplinary reasons. All working persons are insured. Very often young people leaving schools can not find a job and become unemployed.

There are many different forms of help offered to the unemployed. First of all this is the help in finding a job. Very often it is difficult due to the lack of job offers in a moment or due to other reasons. In such a situation a persons claim for benefits. It is clear, that paying benefits should be accompanied with other forms of help, moreover, even if a person does not qualify for benefits, he or she however needs help in finding a job. The benefits differ and depend on fulfilling (or not) special conditions. The help can be obtained by those who are school-leaving students and can not find a job as well as those who are not school-leaving students, worked at least 6 months within the last year and were dismissed not due to disciplinary reasons. The amount of benefit is calculated as follows. The basis for any calculations is 470 PLZ. This amount is announced every year by the state. In general, the benefit for an insured une mployed is 470 PLZ and is paid within 1 year ( 52 weeks), but it can differ in many cases. The most often case is due to the age of a person. Persons above 35 years old have very little chances for finding any job. E.g. for women at age between 57 and 60 and men between 62 and 65, having duration of work longer then 30 years, dismissed due to group dismissing the benefit is higher (120\% of basis benefit), for the other - benefit is in basis amount. The benefit is paid within 30 days after registration for 1 year. For pre-retired benefit can claim also women at age less then 55 who worked at least 30 years as well men younger then 60 years old having at least 35 years of work, who have no other help for the unemployed. The obtained benefit is $160 \%$ of the normal one until they are at retired age. Very often the une mployed persons are offered to attend special courses to learn new skills that may help them in finding a job. 
Each person claiming for benefit is obliged to fulfill a form containing such information like name, last name, profession, education, last job within the last year, working period (in years), average income per person in a family, number of children, etc.

The main task of a social worker is to match those who are looking for a job with firms seeking workers. If it is not possible - as mentioned above such a situation is very often - to give a benefit and/or support other forms of help to the unemployed. Paying benefits should be accompanied with other forms of help; moreover, even if a person does not qualify for benefits, he or she however needs help in finding a job. Assign (or not) a benefit, how high, for how log, to offer other forms of help, etc. depends on many factors and is rather a complicated task. We decided first to classify persons into previously defined groups and then - depending to which group a person has been classified - infer about the forms of helping them.

\section{Classification Description}

The problem of classification is not new. In frame of statistics there are many different techniques to carry on such tasks (Gabbay, Hogger, Robinson, 1995), (Breiman, Friedman, Olshen, Stone, 1984). For our purpose we have chosen one of these techniques, that is the discriminant analysis. The discriminant analysis is especially useful in researches of belongings, that means in classifying an object to one of some groups that have been previously distinguished taking into considerations particular feature from the earlier defined set (Nycz, Smok, 2002.1). The classification relies on conversion of the set of information (signals) about all objects that may be the subject of investigation, into the set of decisions of a form: particular realization (signal) describes the object belonging to i class of similarity of the object (Kolonko, 1980), (Nycz, Smok 2002). The ideal procedure of classification is when it makes no mistakes. In fig. 2 we present the idea of classification. Each point of the limited area represents a single realization. The curve I slits this picture into two subsets representing realizations of the pictures $\mathrm{A}_{1}$ and $\mathrm{A}_{2}$. The curve II slits the same area into such subsets that to all points from the same subset the same decision is being assigned. The areas marked as $\mathrm{B}_{1}$ and $\mathrm{B}_{2}$ represent the set of incorrect decisions. Each measure of the area of incorrect decisions characterizes the applied classification procedure. Different classification rules can be obtained depending on the choice how to measure this area. The classification tasks can be, from the formal point of view, seen as the decision making process. The classification tasks for 2-element set of pictures belong to the two-decisional problems. The classification tasks for multielement set of pictures are assigned to multi-decisional tasks (Kolonko, 1980).

To carry out the classification, many different tools can be used. We have chosen the SPSS. The first step in data preparation for further realized analysis, is grouping. We distinguish the following groups of persons:

\footnotetext{
* school-leaving student,

* persons at age till 55 (for women) and 60 (for men),

* persons at pre-retired age (56-60 for women, 60-65 for men).
}

Then we distinguish features describing these groups like e.g. education, profession, experience, etc. Each new person coming to the office is classified to one of the age group. 


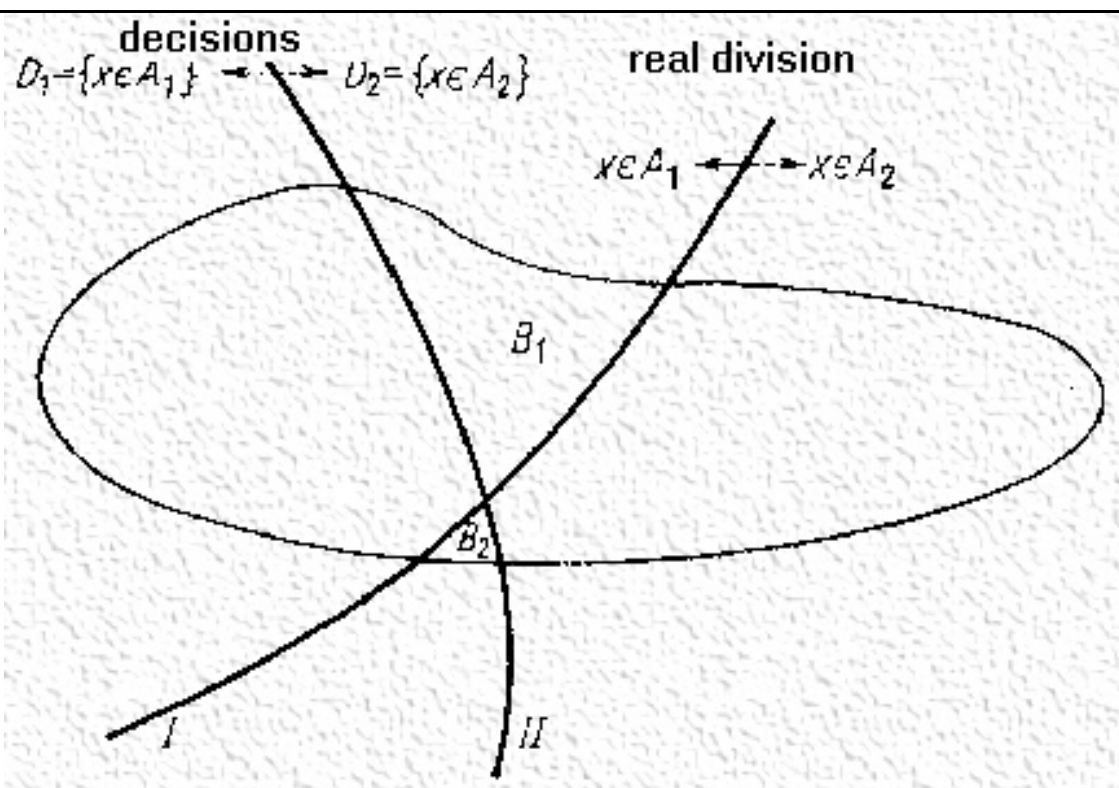

Fig.2: Relations among the real structure of investigated set and decision sets for deterministic task. From: (Kolonko, 1980)

The results of classification are input for reasoning about help for persons claiming for benefits. This part in our model is realized by its deductive part.

\section{Databases and Logic}

Logic can be used as a data model in databases. In frame of such a model we can distinguish:

* data structures,

* operators, and

* integrity rules.

All these three elements are represented in the same unique way as axioms in the logic language (Giarratano, Riley, 1994), (Kifer, 2001).

The deductive database architecture can be seen as follows (fig. 3):

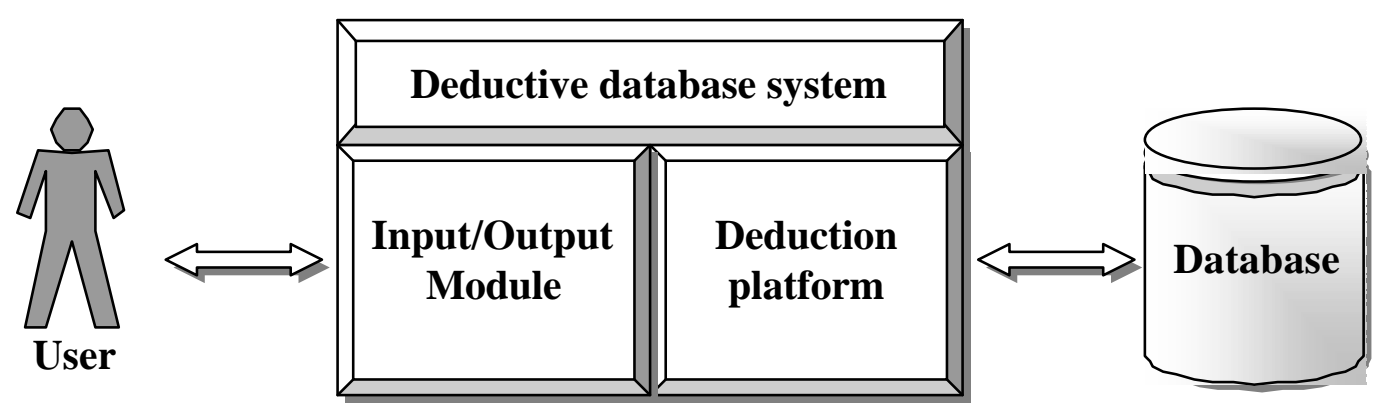

Fig. 3: The deductive database architecture.

(from: Urpi, Teniente, Pastor, Mayol, Martin, Folre 1994, modified) 
As a deductive database system we can treat such a system, which has the ability to define deductive rules and can deduce or infer additional information from the facts stored in a database (Beynon-Davis, 1998), (Ullman, Widom, 2000), (Nycz, Smok, 2000). Deductive rules are often referred to as logic databases. A deductive database (DDB) can be defined as:

$$
\mathrm{DDB}=\{\mathbf{F}, \mathbf{R}, \mathbf{I}\}
$$

where:

$$
\begin{aligned}
& \mathbf{F} \text { - a fact set, } \\
& \mathbf{R} \text { - a deductive rule set, } \\
& \mathbf{I} \text { - an integrity constraints. }
\end{aligned}
$$

In a deductive database sys tem rules are specified through a deductive language in which we specify what to achieve rather then how to achieve it. An inference engine (known also as a deduction mechanism) can infer new facts from the database by interpreting these rules (Gardarin, Valduriez, 1989). The model used for deductive database is closely related to logic programming and the Prolog language. There are many variants of Prolog, e.g. Datalog, Statelog, SWI Prolog, Visual Prolog, which are useful in logic programming.

A deductive database uses two main types of specifications, which are facts and rules. Facts are specified similar to specifications of relations except that it is not necessary to include the attribute names. In a deductive database the meaning of an attribute value in a tuple is determined by its position within the tuple (Gardarin, Valduriez, 1989), (Elmasri, Navathe, 2000).

A deductive rule is a statement about objects and their relationships. This rule can be presented as the following statement:

$$
\mathbf{P} \leftarrow \mathbf{L}_{1} \wedge \ldots \wedge \mathbf{L}_{\mathbf{n}}
$$

where:

$$
\begin{aligned}
& \mathbf{P} \text { - atom, } \\
& \mathbf{L}_{\mathbf{1}}{ }^{\prime} \ldots \mathbf{L}_{\mathbf{n}}-\text { literals representing conditions. }
\end{aligned}
$$

Each literal is either a positive (not negated) atom or a negated one. The integrity constraints are the first order logic rules, which the deductive database fulfills. They are defined as the following expression

$$
\leftarrow \mathbf{L}_{1}^{\wedge} \ldots \wedge \mathbf{L}_{\mathbf{n}}
$$

where $n>=1$ and each literal $\mathrm{L}_{i}(\mathrm{i}=1,2, \ldots \mathrm{n})$ is either not negated or negated atom.

Rules are used when we want to say that a fact depends on a group of other facts. Rules are somewhat similar to relational views. In this context we say they specify virtual relations that are not stored but that can be formed from facts by applying inference mechanism based on the rule specifications (Elmasri, Navathe, 2000).

The evaluation of the Prolog program is realized according to the technique called backward chaining, which involves the top-down evaluations of goals.

As it was said in previous section, results of classification are input for further reasoning by a deductive part of our model. For our research we have used Visual Prolog v.5.2. In the exe mplary fact base we have 8 persons: 3 school-leaving students and 5 other persons claiming for benefit. The fact base is of the following shape:

- for school-leaving students: 


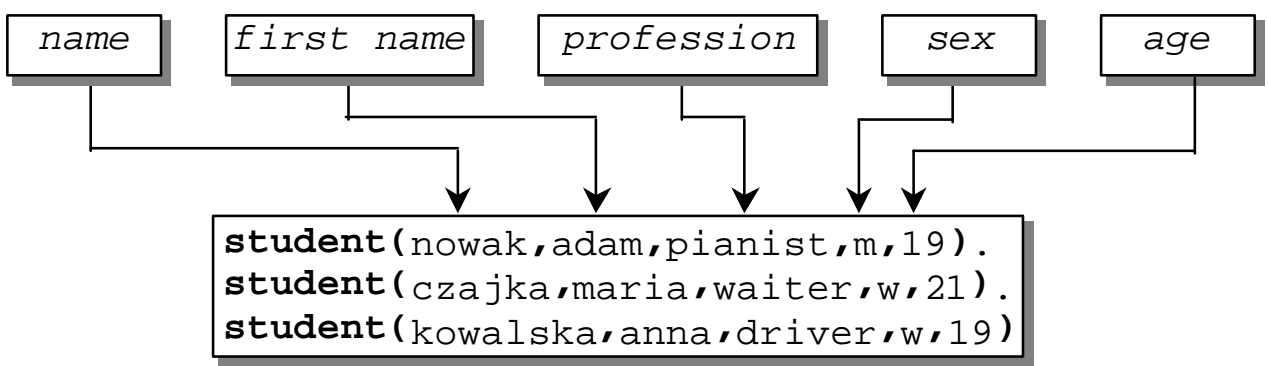

- for other persons:
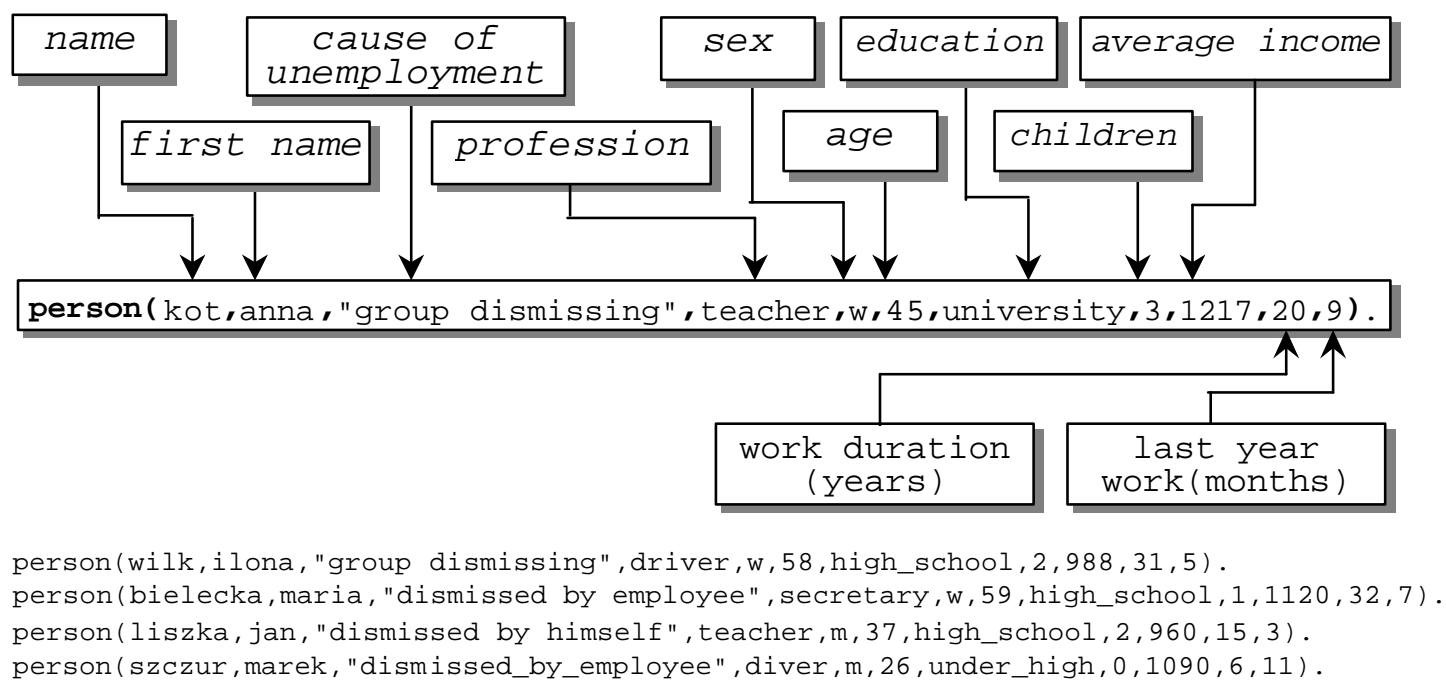

The persons claiming for benefits can posses extra skills that may help them in finding job. They also may want to attend extra courses to learn new skills. These facts are reflected in the fact base in following way:

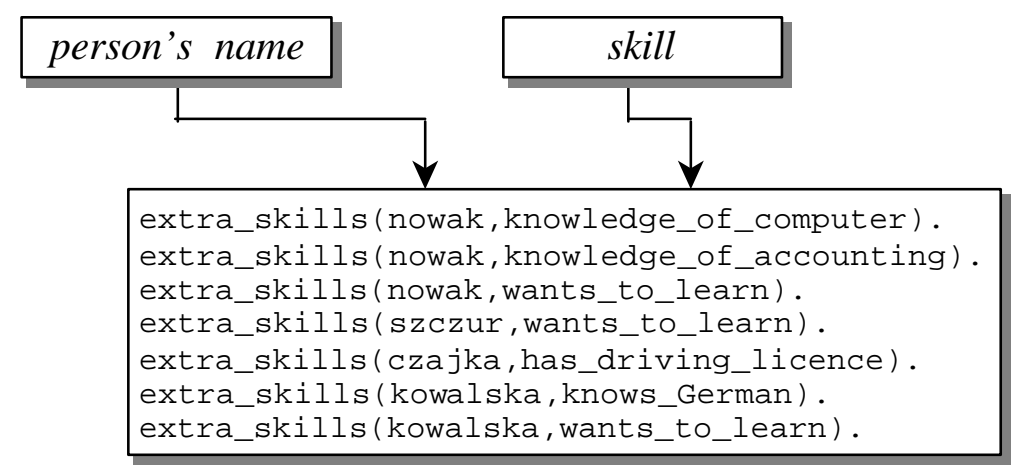

Inferring about decision differs depending on class to which a person has been classified. We will present some possible decisional situations. When it is a school-leaving student who cannot get a job, the clause describing such persons, can look following: 


\section{Example 1.}

The goal can be of the shape:

benefit_assign (Name,First_name, Decision, Benefit, Should_be_paid for_the_following_no_of_weeks).

Answers generated by the system are following:

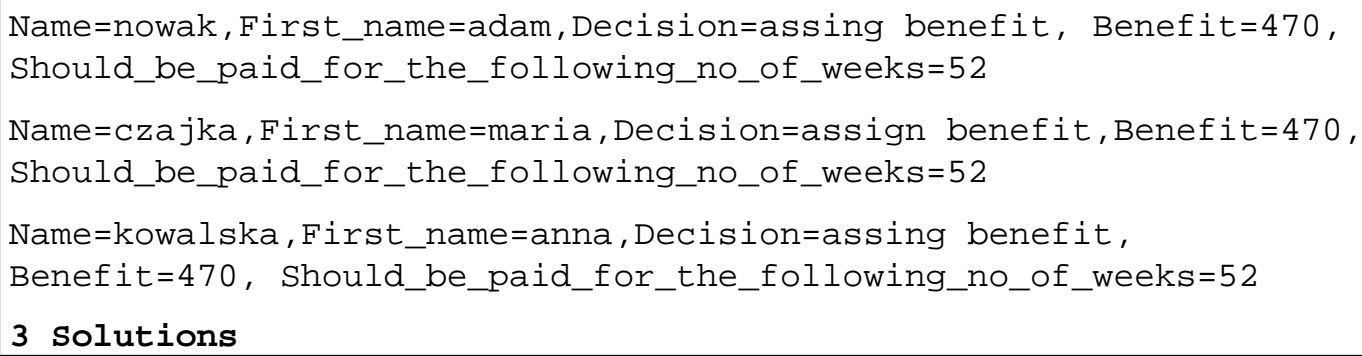

Situation looks different when an unemployed person is not a school-leaving student. He/she is generally older and was working before dismissing. The cause of becoming unemployed is group dismissing. When he/she is at the pre-retired age and it is obvious he/she gets no job. Such a person needs different help than a younger one. In example 2 we show possible help for persons being at pre-retired age.

\section{Example 2.}

the appropriate clause can look like:

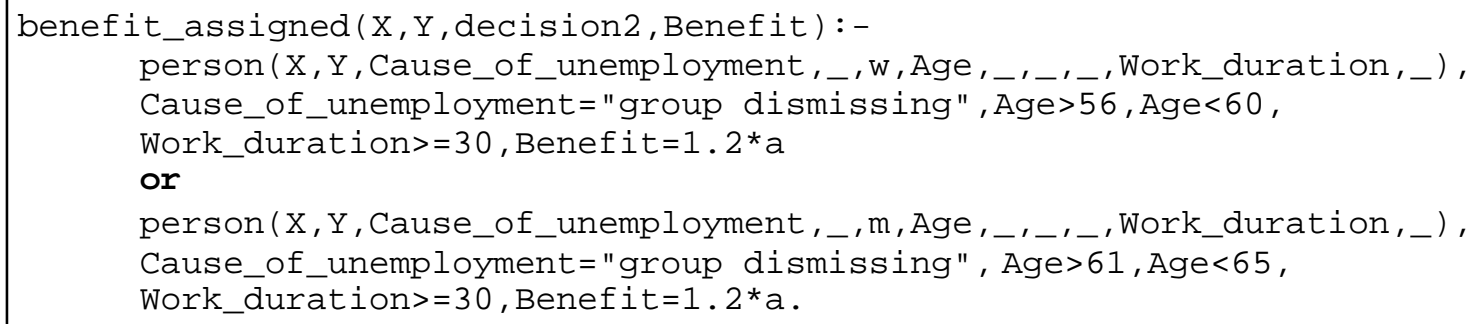

The goal can be:

benefit_assigned (Name, First_name, Decision, Benefit) .

In our test base there is only one person fulfilling conditions:

Name=wilk, First_name=ilona, Decision=benefit: 120\% of basis amount = , Benefit $=564$

\section{Solution}

In the next example (Example 3) we present a situation when persons become unemployed due to different reasons then group dismissing or because disciplinary reasons. They are want to learn new skills, they can change profession and/or to move to another place to live if they get a job, etc. They worked at 
It is possible to define more other situations. Our main aim was to show the possibility of our model and present how to support in intelligent way the process of delivering help to people that became une mployed.

\section{Conclusions}

In this paper we presented a model of combined reasoning about decision what help should be offered to an unemployed person claiming for a benefit. It is not only giving money to those who qualified to such form of help but also suggesting e.g. learning new skills that may be useful in future work. Our model supports the social worker in undertaking the best decision how to help the unemployed persons. It consists of two parts and the reasoning is realized in two steps. Within the first one, the persons are classified into appropriate group. Then, within the group, the deductive inferring is conducted. Such a combined reasoning seems to deliver better decisions that those obtained in traditional way. Our approach seems to be especially useful in situations with large number of persons inquiring for benefits. Nowadays we meet such a situation in our country. But whether this model is really useful it can be proofed only in real life.

\section{References}

Beynon-Davis, P. (1998). Systemy baz danych. Warszawa, WNT, 1998 (in Polish)

Breiman L., Friedman J.H., Olshen R.A., Stone C.J. (1984). Classification and Regression Trees. Wadsworth and Brooks.

Elmasri R., \& Navathe S.B. (2000). Fundamentals of Database Systems, Third Edition, Addison-Wesley.

Gabbay D.M., Hogger C.J., Robin son J.A. (Eds.) (1995). Handbook of Logic in Artificial Intelligence and Logic Progra mming; vol.4: Epistemic and Temporal Reasoning. Clarendon Press, Oxford.

Gardarin G., \& Valduriez P. (1989). Relational Databases and Knowledge Bases. Addison-Wesley Publishing Company, Readings, Massachusetts.

Giarratano J., \& Riley G. (1994). Expert Systems, Principles and Programming. PWS Publishing Company, Boston.

Kifer M. (2001). Deductive and Object Data Languages: A Quest for Integration. Retrieved February 10, 2001 from www.informatik.uni-freiburg.de/ dbis/Publications/

Kolonko, J. (1980). Analiza dyskryminacyjna i jej zastosowania w ekonomii. PWN, Warszawa. (in Polish).

Nycz M., \& Smok B. (2000). Dedukcyjna baza danych jako przyklad inteligentnej bazy danych, Materialy Konferencyjne z Konferencji nt. "Pozyskiwanie wiedzy z baz danych", Wydawnictwo Akademii Ekonomicznej im. O. Langego we Wroclawiu, Prace Naukowe nr 850, Wroclaw, 2000 (in Polish)

Nycz M., \& Smok B. (2001). Data mining - metoda wspomagania procesow decyzyjnych. In: III Krajowa konferencja „Metody i systemy komputerowe w badaniach i projektowaniu inzynierskim, Tadeusiewicz R., Ligeza A., Szymkat M. (eds), Krakow 2001 (in Polish)

Nycz M., \& Smok B. (2002). Mozliwosci wykorzystania metod statystycznych do filtracji danych. In: Wspomaganie Decyzji - Integracja Systemow, VIII Konferencja z cyklu Komputerowe Systemy wielodostepne KSW'2002, BydgoszczCiechocinek 2002 (in Polish)

Nycz M., \& Smok B. (2002.1). Wybrane metody ekstrakcji wiedzy w przedsiebiorstwie. In: Informatyka Ekonomiczna, Prace Naukowe nr 953, Wydawnictwa Akademii Ekonomicznej im. O.Langego we Wroclawiu, Wroclaw 2002

Ullman J.D., \& Widom J. (2000). Podstawowy wyklad z systemow baz danych. WNT, Warszawa (in Polish).

Urpi T., Teniente E., Pastor J.A., Mayol E., Martin C., Folre D. (1994). Towards a System for the Integrated Treatment of Updates and Rule Enforcement in Deductive Databases. Retrieved December 7, 1999 from http://wwwlsi.upc.es/ martin/home ang.html 


\section{Biographies}

Nycz Malgorzata, Ph.D. Eng. is a lecturer in the Faculty of Management and Computer Science, Wroclaw University of Economics, Poland. Dr Nycz has authored over 50 publications mostly oriented on intelligent systems topics and distance learning issues. In recent years she has been engaged in the international project 'Knowledge Acquisition and Intelligent Distributed Learning in Resolving Managerial Issues" with Belgium. Her current research is in intelligent systems with focus on knowledge discovery from databases and modern education including e-learning processes.

Smok Barbara, Ph.D. is a lecturer in the Faculty of Management and Computer Science, Wroclaw University of Economics, Poland. Dr Smok has authored over 45 publications mostly oriented on databases, intelligent systems topics and distance learning issues. In recent years she has been engaged in the international project "Knowledge Acquisition and Intelligent Distributed Learning in Resolving Managerial Issues" with Belgium. Her current research is in intelligent systems with focus on data warehouses, knowledge bases, and modern education including e-learning processes. 